\title{
Nicotinism and the knowledge of consequences of laryngectomy among university students
}

\begin{abstract}
Agnieszka Hamerlinska, Nicotinism and the knowledge of consequences of laryngectomy among university students. Interdisciplinary Contexts of Special Pedagogy, no. 30, Poznań 2020. Pp. 67-87. Adam Mickiewicz University Press. ISSN 2300-391X. e-ISSN 2658-283X. DOI: https:// doi.org/10.14746/ikps.2020.30.04
\end{abstract}

Nicotine addiction is currently one of the most serious health and social problems worldwide, which contributes to the development of numerous diseases, including, above all, laryngeal cancer, which may lead to laryngectomy. The consequences of losing one's larynx are irreversible. The objective of the study presented in this paper was to describe the knowledge of the consequences of radical laryngectomy among students pursuing a variety of majors. The study covered 194 people (119 non-smokers and 75 smokers), who took part in diagnostic survey based on a bespoke questionnaire. Based on the study in question, the author determined that the level of knowledge about the consequences of laryngectomy among the majority of students is average to low, while smoking students have an average awareness of these consequences. Moreover, it turned out that age, gender, major and the number of smokers in students' closest circles do not determine the knowledge about the subject at hand. The results of the study indicate that the anti-smoking public service campaigns addressed to youth should include information about both the risk of diseases and their consequences, which may significantly reduce the quality of life and hinder everyday functioning.

KEY WORDS: nicotinism, knowledge, laryngeal cancer, health 


\section{Introduction}

Nicotine is an alkaloid found in large quantities in tobacco; it binds to the acetylcholine receptors of the autonomic ganglia, adrenal medulla and central nervous system, impacting both the sympathetic and parasympathetic parts of the nervous system. ${ }^{1}$ It stimulates the central nervous system, in particular the reward system located in the limbic system, dilates peripheral blood vessels, increases the heart rate and arterial pressure, reduces the tension of striated muscles, accelerates peristalsis and stimulates the secretion of gastrointestinal glands, thus leading to addiction. ${ }^{2}$ According to the International Classification of Diseases, nicotine dependence is defined cluster of behavioural, cognitive and physiological phenomena in which the use of tobacco takes on a much higher priority than other behaviours that once had a greater value. ${ }^{3}$ The first cigarette is most often smoked between the ages of 16 and 18 and is due to curiosity and peer pressure. 4

Nicotine addiction is currently one of the most serious health and social problems worldwide, which contributes to the development of numerous diseases, including, above all, laryngeal cancer, which may lead to laryngectomy. The consequences of losing one's larynx are irreversible. The objective of the study presented in this paper is to describe the knowledge of the consequences of radical laryngectomy among students pursuing a variety of majors.

${ }^{1}$ Ł. Szczygieł, Uzależnienie od tytoniu. Gazeta Farmaceutyczna, 2008, 4, pp. 42-45.

${ }^{2}$ Ibid.

${ }^{3}$ ICD-11 International Classification of Diseases 11th Revision.

${ }^{4}$ M. Szpringer, A. Makowska, M. Olędzka, Uzależnienie od nikotyny i ocena skuteczności rzucania palenia u dorostych. Medycyna Środowiskowa - Enviromental Medicine, 2016, 19(1), pp. 43-50. 


\section{Nicotinism as a lifestyle disease}

Nicotinism is also referred to as the tobacco smoking epidemic. ${ }^{5}$ As a continent, Europe is characterised by the highest prevalence of smokers in the world, with $68.9 \%$ of the adult population and $38.1 \%$ of children. Among adults, $44.6 \%$ of men and $24.3 \%$ of women smoke, with $21.5 \%$ boys, $16.6 \%$ girls smoking among children. It is also worth noting that tobacco consumption in Poland is one of the highest in the world. ${ }^{6}$

In 2013, a survey was conducted among Poles to gather information on their smoking habits. Most smokers turned out to be men; however, there has been a marked $8 \%$ drop in smoking among men compared to the 1980s and 1990s, while the indicators for women have not budged. The authors also pointed out some worrying trend - namely that $14 \%$ of boys and $10 \%$ of girls aged $14-19$ admitted to being addicted to nicotine. ${ }^{7}$

Nicotine addiction is currently one of the most serious health and social problems worldwide, while smokers are unable to name more than 4-5 tobacco-related diseases. ${ }^{8}$ What is more, they often make attempts to quit, but mostly go back to smoking; which indicates that the knowledge of the consequences is insufficient. ${ }^{9}$ Kanicka et al. note that it is particularly important that future health

${ }^{5}$ L. Wengler, P. Popowski, E. Adamska-Pietrzak, M. Balwicka-Szczyrba, Ł. Balwicki, I. Adrych-Brzezińska, K. Trzeciak-Bilska, Wybrane aspekty polskiego prawa antytytoniowego jako narzędzia ograniczającego epidemię palenia tytoniu, Annales Academiae Medicae Gedanensis. 2012, 42, pp. 81-94.

${ }^{6}$ J. Książek, J. Korczyńska, S. Terech, Problem nikotynizmu w aspekcie profilaktyki raka ptuca wśród studentów gdańskich uczelni, Medycyna Rodzinna, 2013, 4, pp. 137-142.

7 Report from a nationwide survey on attitudes towards smoking, TNS Poland for the Chief Sanitary Inspectorate, Warsaw 2013 [20].

8 The most frequently mentioned are lung and tongue cancer, arteriosclerosis and hypertension.

${ }^{9}$ M. Szpringer, A. Makowska, M. Olędzka, Uzależnienie od nikotyny i ocena skuteczności rzucania palenia u dorostych. Medycyna Środowiskowa - Enviromental Medicine, 2016, 19(1), pp. 43-50. 
professionals, who will be responsible for disease prevention, are the best acquainted with the consequences of smoking.

Cigarette smoking is one of the most important risk factors that can lead to many diseases. ${ }^{10}$ Smoking-related diseases shorten the smokers' lives by more than 8-9 years. ${ }^{11}$ In the case of cardiovascular diseases (including coronary artery disease), the smoking factor increases the mortality rate by $160 \%$; what is more, smoking results in respiratory diseases, cancers and strokes. ${ }^{12}$ Cigarette smoking is also one of the factors impacting dementia. ${ }^{13}$

Various anti-smoking campaigns are being conducted, highlighting the negative consequences of smoking; however, their effectiveness remains too low and subject to verification. One example of this is a survey conducted among Spanish students in 2009. The researchers first established the number of cigarette smokers, then they held prevention classes, featuring a leaflet on the consequences of smoking. On the basis of the study, it turned out that there was no evidence of any effectiveness of the advice, information contained in the leaflet. The prevalence of smoking remained at a high level. In reality, the survey even showed an increase in smoking among respondents over two years. ${ }^{14}$

10 Ł. Bojkowski, Mojs E., Palenie tytoniu i konsekwencje tego nałogu dla zdrowia osób w podeszłym wieku, Polski Przegląd Nauk o Zdrowiu, 2017, 2(51), pp. 220-224.

11 R. Doll, R. Peto, J. Boreham, I. Sutherland, Mortality in relation to smoking: 50 years' observations on male British doctors, BMJ, 2004 26, 328(7455), 1519, https:/ / www. bmj.com/content/bmj/328/7455/1519.full.pdf

12 M. Łukasik, W. Kozubski, Zespół metaboliczny jako czynnik ryzyka niedokrwiennego udaru mózgu, Neurologia i Neurochirurgia Polska, 2012, 46, pp. 271-278.

13 L.J. Launer, K. Andersen, M.E. Dewey, L. Letenneur, A. Ott, L.A. Amaducci, C. Brayne, J.R. Copeland, J.F. Dartigues, P. Kragh-Sorensen, A. Lobo, J.M. MartinezLage, T. Stijnen, A. Hofman, “Rates and risk factors for dementia and Alzheimer's disease: results from EURODEM pooled analyses. EURODEM Incidence Research Group and Work Groups", European Studies of Dementia. Neurology 1999, 1, 52(1), pp. 78-84.

${ }^{14}$ Galbe, José Traver, P. Navarra, B. Martínez, A. Galve, Z. Aliaga, Y. Duplá, M. Jimenez, V. Torres, S. Cazorla, I. Ibarrondo, R. Magallón-Botaya, B. Oliván-Blázquez, M. Alastuey, L. Escosa, E. Planas, “Brief advice for the prevention of the 
Similar studies were conducted in Poland in 2008 among students of medical faculties at the Medical University of Białystok, resulting from an educational project under the "Programme of Health and Socio-Economic Policy for the Reduction of Tobacco Consumption". ${ }^{15}$ It turned out that the percentage of smoking students has also increased throughout the two-year period. The only positive outcome of the study concerned respondents' attitude - the majority of students supported the draft act introducing a total ban on smoking in Poland. ${ }^{16}$

Smoking in public places has been banned in Poland since 2010,17 as a result of the Tobacco Control Act, which came into force on 8.04.2010. The legislation places strong emphasis on protecting the right of non-smokers to live in a smoke-free environment, promoting health by supporting smoke-free lifestyles without tobacco products, as well as educational and information activities. ${ }^{18}$ Moreover, the European Union Tobacco Products Directive of 29.04.2014 introduced many changes concerning the appearance, sale and promotion of tobacco products and tobacco derivatives. From 20.05.2016, EU countries need to respect the following rules:

- the obligation to cover at least $65 \%$ of the total area of new cigarette packs with warnings concerning the health consequences of smoking;

- the obligation for the manufacturer to place clearer and more visible information on every possible surface of the packaging;

nicotinism in students of $2^{\circ}$ to $4^{\circ}$ of Secondary Obligatory Education of Saragossa", Pediatria de Atencion Primaria, 2009, 11, pp. 49-63.

15 https://pssesiemiatycze.org/promocja-zdrowia/program-ograniczania-zdro wotnych-nastepstw-palenia-tytoniu-w-polsce.html

16 Bielska D., Trofimiuk E., Kurpas D., Program nikotynizmu w świetle edukacji na Wydziale Lekarskim i Wydziale Pielegniarstwa Uniwersytetu Medycznego w Białymstoku, Przegląd Lekarski, 2008, 65, 10, pp. 568-571.

17 Act of 9 November 1995 on Health Protection against the Consequences of Tobacco and Tobacco Products.

18 Wengler L., Popowski P., Adamska-Pietrzak E., Balwicka-Szczyrba M., Balwicki Ł., Adrych-Brzezińska I., Trzeciak-Bilska K., Wybrane aspekty polskiego prawa antytytoniowego jako narzędzia ograniczającego epidemię palenia tytoniu, Annales Academiae Medicae Gedanensis. 2012, 42, pp. 81-94. 
- the ban on manufacturing small cigarette packs;

- the lower limit of the number of cigarettes in a pack set to 20;

- a ban on promotion of tobacco products;

- ban on on-line trade in tobacco products imposed by EU Member States. ${ }^{19}$

\section{Consequences of laryngectomy}

As previously noted, smoking leads to respiratory diseases and cancer. The carcinogenic effect of tobacco smoke is associated with $80-90 \%$ of all laryngeal cancer cases ${ }^{20}$, which constitutes a significant clinical problem and is the second most common respiratory cancer in Poland. Laryngeal cancer is most often diagnosed at an advanced stage, which requires surgical treatment, often resulting in total laryngectomy. Complete removal of the larynx (laryngectomia totalis) is done in the case of bilateral cancer, including epiglottis and sub-glottis. ${ }^{21}$ First a tracheotomy is performed and then the patient is intubated through an opening in the trachea in order to enable breathing.. The laryngectomy procedure includes cutting off the larynx from the top of the tongue and throat and from the bottom of the trachea. During the procedure, the hyoid bone is also removed, along with the pre-epiglottic space. The walls of the lower throat are stitched together and a feeding tube is inserted into the oesophagus as the throat heals. The remaining stump of the trachea is then permanently stitched to the neck skin, forming a permanent opening referred to as tracheostoma. ${ }^{22}$

19 http:/ / ec.europa.eu/health/tobacco/products/index_pl.htm

${ }^{20} \mathrm{~J}$. Kamuda-Lewtak, Typologia zaburzeń mowy w chorobach nowotworowych krtani, [in:] Grabias S., Kurkowski M. (eds.), Logopedia - Teoria zaburzeń mowy, Podręcznik akademicki, Lublin 2015, pp. 515-527.

21 A. Bruzgielewicz, Leczenie chirurgiczne, [in:] Janczewski G., Osuch-Wójcikiewicz E., Rak krtani i gardła dolnego, Bielsko-Biała 2002, pp. 143-175.

22 J. Kamuda-Lewtak, Typologia zaburzeń mowy w chorobach nowotworowych krtani, [in:] Grabias S., Kurkowski M. (eds.), Logopedia - Teoria zaburzeń mowy, Podręcznik akademicki, Lublin 2015, pp. 515-527. 
Laryngectomy is associated with many irreversible changes, which have an impact on the quality of life (Table 1).

Table 1. Changes after laryngectomy.

\begin{tabular}{|c|c|c|}
\hline \multirow{5}{*}{ 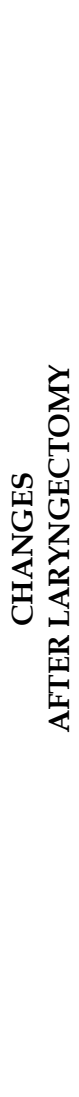 } & ANATOMICAL & $\begin{array}{l}\text { larynx removal } \\
\text { possible removal of other elements such as lymph nodes } \\
\text { tracheostoma }\end{array}$ \\
\hline & FUNCTIONAL & $\begin{array}{l}\text { inability to breathe in and out through the mouth } \\
\text { shortening and inhaling of air with impurities } \\
\text { inhalation of unheated air } \\
\text { lack of air humidification } \\
\text { loss of nasal reflexes } \\
\text { loss of voice and phonetic speech } \\
\text { loss of the ability to blow, breathe and yawn } \\
\text { lack of smell } \\
\text { inability to snore } \\
\text { no possibility to choke during swallowing } \\
\text { impaired cough reflex } \\
\text { problems with pushing while defecating and urinating } \\
\text { inability to give birth naturally } \\
\text { inability to dive and swim }\end{array}$ \\
\hline & PSYCHICAL 23 & $\begin{array}{l}\text { lowered self-esteem } \\
\text { depression } \\
\text { sense of rejection and loneliness } \\
\text { fear of the disease returning }\end{array}$ \\
\hline & SOCIAL & $\begin{array}{l}\text { possible job loss } \\
\text { being referred to as a pensioner, disabled, "cripple" } \\
\text { possible separation, divorce, family break-up } \\
\text { losing the ability to laugh, cry and shout out loud }\end{array}$ \\
\hline & AESTHETIC & $\begin{array}{l}\text { visible scarring } \\
\text { need to wear a tracheostomy tube and/or a stoma protec- } \\
\text { tion scarf }\end{array}$ \\
\hline
\end{tabular}

Source: Hamerlińska-Latecka, 2017.24

${ }^{23}$ May be temporary.

${ }^{24}$ A. Hamerlińska-Latecka, Metodyka logopedyczna w przypadku osób po laryngektomii catkowitej, Studia Logopaedica, 2017, VI, pp. 89-100. 


\section{Author's own research results}

The author conducted a pilot study concerning the knowledge of the consequences of laryngectomy among students with and without nicotine dependence. The theoretical objective of the study was to describe the students' knowledge of the consequences of removal of larynx, with particular emphasis on smokers. The practical aim in turn was to develop guidelines for the development of health education on preventing the consequences of smoking tobacco. The following study questions were formulated:

1. What is the level of knowledge about the consequences of laryngectomy among the students participating in the survey?

1.1. Which of the activities that change after laryngectomy are known to the respondents?

1.2. Is there a connection between gender, age, major and the number of smokers in the students' immediate circles and the knowledge of the consequences of laryngectomy?

2. What is the level of knowledge about the consequences of laryngectomy among smoking students participating in the survey?

2.1. Which of the activities that change after laryngectomy are known to smoking respondents?

2.2. Is there a connection between gender, age, major and the number of smokers in the smoking students' immediate circles and the knowledge of the consequences of laryngectomy?

The following research hypotheses have been established for the above-mentioned study questions:

1. The level of knowledge about the consequences of laryngectomy among the students participating in the survey varies.

1.1. Students have different levels of knowledge about all activities that change after laryngectomy.

1.2. There is a connection between gender, age, major and the number of smokers in the students' immediate circles and the knowledge of the consequences of laryngectomy. 
2. The level of knowledge about the consequences of laryngectomy among smoking students participating in the survey is low.

2.1. Smoking students do not have knowledge concerning all activities that change after laryngectomy.

2.2. There is a connection between gender, age, major and the number of smokers in the smoking students' immediate circles and the knowledge of the consequences of laryngectomy.

The conducted study assumed the following independent variables: age, gender, major, number of smokers in the closest circles, nicotine dependence. The knowledge of the consequences of laryngectomy was stated to be a dependent variable. Indicators for individual variables are presented in Table 2 .

Table 2. Variables and indicators used in the study

\begin{tabular}{|c|c|c|}
\hline $\begin{array}{l}\text { Variable } \\
\text { type }\end{array}$ & Variables & Indicators \\
\hline \multirow{5}{*}{$\begin{array}{l}\text { Independent } \\
\text { variables }\end{array}$} & Age & $\begin{array}{l}\text { In figures, provided by the re- } \\
\text { spondents }\end{array}$ \\
\hline & Sex & Woman/Man \\
\hline & Major & Provided by the respondents \\
\hline & $\begin{array}{l}\text { Number of smokers in the closest } \\
\text { circles }\end{array}$ & $\begin{array}{l}\text { Number provided by the re- } \\
\text { spondents }\end{array}$ \\
\hline & Nicotine dependence & $\begin{array}{l}\text { Smoker } \\
\text { Non-smoker }\end{array}$ \\
\hline $\begin{array}{l}\text { Dependent } \\
\text { variable }\end{array}$ & $\begin{array}{l}\text { Knowledge of the consequences } \\
\text { of laryngectomy }\end{array}$ & $\begin{array}{l}\text { Levels: very low, low, average, } \\
\text { high, very high }\end{array}$ \\
\hline
\end{tabular}

The study employed a diagnostic survey, with a bespoke questionnaire prepared by the author, which consisted of a short bio section and a list of 30 actions. The author decided to carry out the study among students, since the period of studying is associated with spending time at social gatherings, which encourages smoking 
(as presented in the theoretical part of this paper). In addition, the period of the final exam and education-related stress can be conducive to developing a smoking habit. The study focused on Polish students due to the fact that Poland remains one of the countries of Europe with high prevalence of nicotinism.

The respondents were supposed to indicate which everyday activities change as a result of laryngectomy. Of the 40 answers, 19 were correct. The following score was adopted to determine the levels of knowledge of the consequences of total laryngectomy:

- very low - 0 to 3 correct answers;

- low - 4 to 7 correct answers;

- average - 8 to 11 correct answers;

- high - 12 to 15 correct answers;

- very high - from 16 to 19 correct answers.

The questionnaires were distributed to 218 students, of which 24 were rejected because they were incomplete. The number of respondents finally amounted to 194 people (100\%). The average age of the students taking part in the survey was 22 years (minimum 18, maximum 41, standard deviation 2.5). The group of respondents included 141 women (73\%) and 53 men (27\%). The respondents represented various majors: early school education - 38 people $(20 \%)$, education -27 people $(14 \%)$, speech therapy -8 people $(4 \%)$, archive studies - 52 people $(27 \%)$, vocal studies - 18 people $(9 \%)$, mechanics and mechanical engineering - 21 people $(11 \%)$, medicine - 19 people $(10 \%)$, social work - 4 people $(2 \%)$, journalism - 3 people $(2 \%)$, as well as one student representing administration, architecture, forensic biology and obstetrics (1\% each), respectively. Among the respondents were 119 (61\%) non-smokers and 75 (39\%) smokers. The respondents have an average of 2 smokers in their closest circles (minimum 0, maximum 8, standard deviation 1.63).

To begin with, the study determined the level of knowledge about the consequences of laryngectomy of the participating students (Table 3).

Based on the results of the conducted study, it turned out that the majority of the surveyed students [80 respondents $(41 \%)$ ] had an 
Table 3. The levels of knowledge about the consequences of laryngectomy among the students participating in the survey

\begin{tabular}{|l|c|}
\hline $\begin{array}{c}\text { Level of knowledge } \\
\text { of the consequences of laryngectomy }\end{array}$ & $\mathrm{N}=194(100 \%)$ \\
\hline Very low & 14 people $(7 \%)$ \\
\hline Low & 64 people $(33 \%)$ \\
\hline Average & 80 people $(41 \%)$ \\
\hline High & 29 people $(15 \%)$ \\
\hline Very high & 7 people $(4 \%)$ \\
\hline
\end{tabular}

average level of knowledge about the consequences of laryngectomy. The second group was made up of students with low level of knowledge [64 respondents (33\%)], with people with high level of knowledge coming in third [29 respondents (15\%)], with people with very low level [14 respondents $(7 \%)$ ], and very high level of knowledge [7 respondents (4\%)] taking fourth and fifth place, respectively.

There were 19 activities in the survey, which change after the larynx is removed. Figure 1 shows the number of respondents who indicated that a given activity changes due to laryngectomy.

The participants of the study usually associated larynx removal with changes in speech and using one's voice, which resulted in the most frequently marked answers being: singing - 173 respondents $(89 \%)$, speaking - 170 respondents $(88 \%)$, shouting - 167 respondents $(86 \%)$, whispering - 130 respondents $(67 \%)$. Then, the students had knowledge of the changes resulting from shortened airway, including coughing - 144 respondents (74\%), expectoration - 136 respondents $(70 \%)$, breathing - 117 respondents $(60 \%)$, blowing 76 respondents $(39 \%)$, blowing one's nose -60 respondents $(31 \%)$, sniffing and smelling - 48 respondents (25\%), yawning - 30 respondents $(15 \%)$. They also noted a relationship between losing one's larynx and decreased pushing function concerning natural birth -31 respondents $(16 \%)$, lifting weights -13 respondents $(7 \%)$, defecation -38 respondents $(20 \%)$, urination -1 respondent $(1 \%)$. 


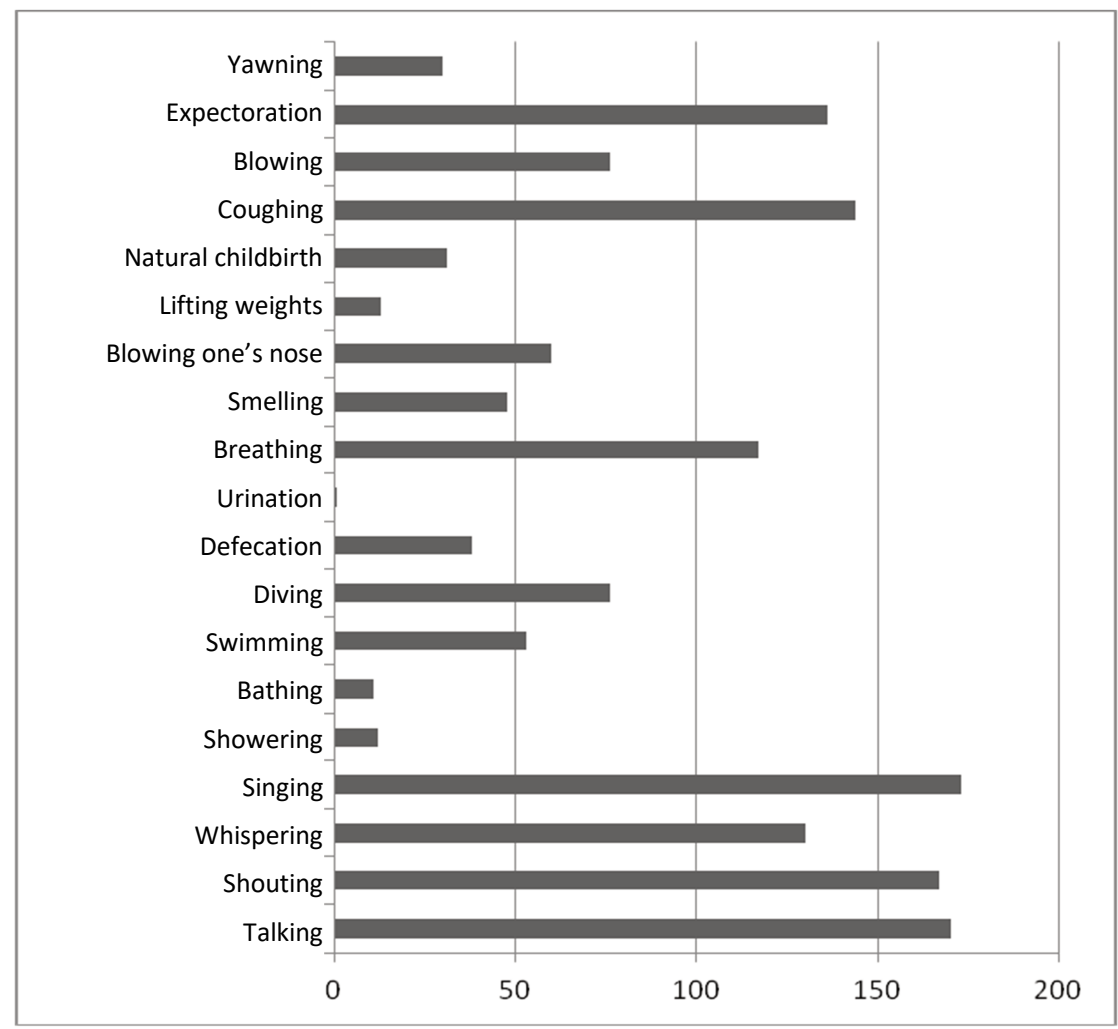

Fig. 1. Activities changed after the removal of the larynx and the respondents' answers

The students also took note of the fact that resection of the larynx changes a number of other activities, including diving (17\%), swimming - 53 respondents $(27 \%)$, showering -12 respondents $(6 \%)$, and bathing - 11 respondents $(6 \%)$.

Then the examined variables were analysed statistically. The author assumed that the knowledge of the consequences of laryngectomy is a dependent variable, and age, gender, major, being a smoker/non-smoker, as well as the number of people smoking in the closest circles were selected to be independent variables. 
It turned out that there was no correlation between the age of the respondents and their knowledge about the consequences of laryngectomy (Spearman's rank correlation did not display any statistical significance). After applying Mann-Whitney's U test, the results showed that the sex of the examined students also did not lead to differentiated knowledge about the consequences of total laryngectomy. There was also no connection between students' major and knowledge of the consequences of laryngectomy, according to the Kruskal Wallis test. Using Student's t-test, the author established that there was no connection between being a smoker and knowing the consequences of laryngectomy, and using the Kruskal Wallis test did not highlight such a relationship. In addition, no correlation (according to Spearman's rank correlation) was discovered between the number of smokers in the immediate circles of the respondent and their knowledge of the consequences of laryngectomy.

The second part of the analysis focused on smokers - 75 of all respondents, including 62 (83\%) women and 13 (17\%) men. The average age of the smoking cohort was 21 years (the youngest respondent was 19, the oldest was 27, standard deviation 1.72). The distribution of the group of people with nicotine dependence according to their majors was as follows: 27 respondents (36\%) - education, $16(21 \%)$ - archive studies, $6(8 \%)$ - mechanics and mechanical engineering, 5 respondents $(7 \%)$ - early childhood education, $4(5 \%)$ - vocal studies, 4 (5\%) - social work, $3(4 \%)$ - speech therapy, $3(4 \%)$ - medicine, $3(4 \%)$ - journalism $(4 \%), 1$ respondent $(1 \%)$ obstetrics, 1 respondent $(1 \%)$ - forensic biology, 1 respondent $(1 \%)$ information architecture, 1 respondent $(1 \%)$ - administration. The smoking respondents have an average of 3 smokers in their closest circles (minimum 0, maximum 8, standard deviation 1.581).

The level of knowledge about the consequences of laryngectomy among the smoking students participating in the survey varied (Table 8).

It turns out that among smoking students, the majority had an average level of knowledge about the consequences of laryngectomy $[28(37 \%)]$, followed by low level [26(35\%)], very low level [9(12\%)], high level [8(11\%)], and very high level [4 (5\%)]. 
Table 8. The levels of knowledge about the consequences of laryngectomy among smoking students participating in the survey

\begin{tabular}{|l|c|}
\hline $\begin{array}{c}\text { Level of knowledge } \\
\text { of the consequences of laryngectomy }\end{array}$ & $\mathrm{N}=75(100 \%)$ \\
\hline Very low & $9(12 \%)$ \\
\hline Low & $26(35 \%)$ \\
\hline Average & $28(37 \%)$ \\
\hline High & $8(11 \%)$ \\
\hline Very high & $4(5 \%)$ \\
\hline
\end{tabular}

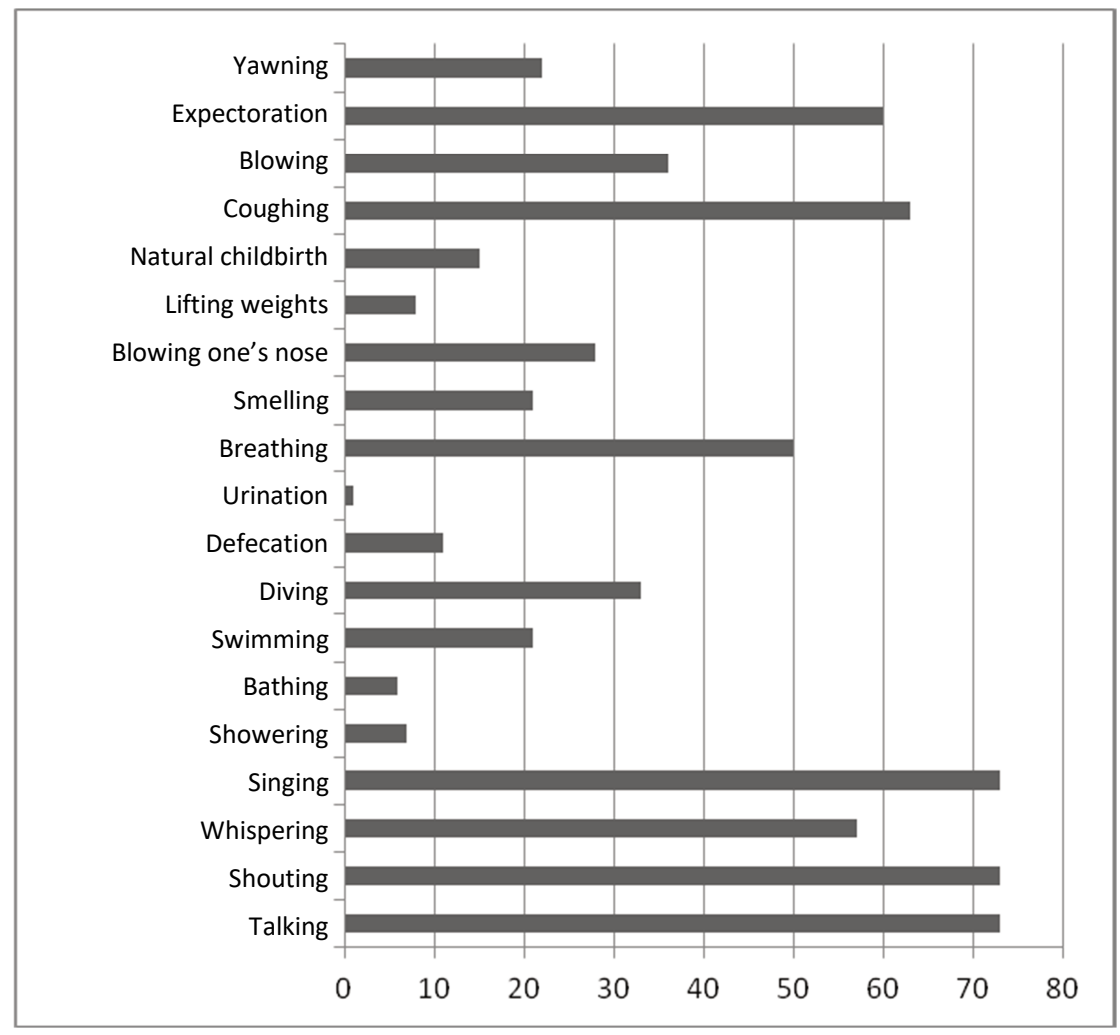

Fig. 2. Activities changed after the removal of the larynx and the smoking respondents' answers 
Figure 2 shows the number of smoking respondents who indicated that a given activity changes due to laryngectomy.

Cigarette smokers usually associated laryngectomy with changes concerning speech and using one's voice, leading to the most frequent answers being: singing, shouting and speaking - 73 smoking respondents $(97 \%)$ and whispering- - 57 (76\%). Then, the smoking students indicated changes resulting from shortened airway, including coughing - 63 respondents (84\%), expectoration - 60 respondents $(80 \%)$, breathing - 50 respondents $(67 \%)$, blowing - 36 respondents $(48 \%)$, blowing one's nose - 28 respondents $(37 \%)$, sniffing and smelling - 21 respondents $(28 \%)$, yawning - 22 respondents $(29 \%)$. They also noted a relationship between losing one's larynx and decreased pushing function concerning natural birth -15 respondents $(20 \%)$, lifting weights -8 respondents $(11 \%)$, defecation - 11 respondents $(15 \%)$, urination -1 respondent $(1 \%)$. The respondents also were aware of changes concerning a number of other activities, including diving - 33 respondents (44\%), swimming - 21 respondents $(28 \%)$, showering -7 respondents $(9 \%)$, and bathing -6 respondents $(8 \%)$.

The individual variables were subjected to statistical analysis. It turned out that there was no correlation between the age of the smoking respondents and their knowledge about the consequences of laryngectomy (Spearman's rank correlation did not display any statistical significance). Additionally, the sex of students with nicotine dependence did not differentiate the knowledge about the consequences of total laryngectomy (Mann-Whitney $U$ test did not result in any statistical significance). Likewise, no connection was noted between the student's major and their knowledge of the consequences of laryngectomy, according to the Kruskal Wallis test. There was also no correlation between the number of smokers in the closest circles of the smoking students and their knowledge, according to Spearman's rank correlation, which showed no statistical significance. 


\section{Conclusions of the study and summary}

The study of knowledge on the consequences of laryngectomy can be considered as a preventive measure. It is important to know not only the direct consequences of nicotinism, which include cancer, but also its aftermath, so to speak. Nicotine dependence is one of the leading causes of laryngeal cancer. In the case of a diagnosed cancer at a highly advanced stage, the most common treatment is total laryngectomy 25 , the consequences of which result in a significant impact on everyday life, both physical, mental and social. The study conducted by the author showed that students have mostly low-to-average level of knowledge about the consequences of laryngectomy. The surveyed group, however, also included people with very high, high and very low levels of knowledge. It is worth noting, however, that both smoking and non-smoking cohorts were dominated by respondents with an average level of knowledge of the consequences of laryngectomy, closely followed by people with a low level of knowledge. The study also shows that students' levels of knowledge about the consequences of laryngectomy varies.

Further analysis of the study results shows that students are not aware of all the activities that change in the aftermath of laryngectomy, and this applies to both smokers and non-smokers. Respondents associate larynx removal mainly with loss of speech and changes in voice: inability to shout and sing, with significantly less respondents indicating whispering. The respondents also pointed to the changes resulting from shortened airway. The most common responses referred to coughing, choking, and blowing. ${ }^{26}$ Unfortunately, few students were aware of the loss of sense of smell, which can save lives (for example in the case of fire) or improve its quality (when it comes to smelling perfumes or cooking). Half of the re-

25 In Poland, about 500 total laryngectomies are performed annually. In 2015, laryngeal cancer was diagnosed in 2171 men and 355 women, in 2017 in 1933 men and 291 women.

${ }^{26}$ It is unknown how the participating students understood this or how did they imagine such a change, since the first two activities are carried out via the stoma, and the last one is no longer possible due to the loss of the larynx. 
spondents noted that the resection of a larynx is associated with the inability to dive, less people indicated swimming (which is only possible with appropriate equipment, but it is worth noting that swimming is associated with the risk of death). Students are also not aware that when taking a shower, patients after laryngectomy need to position themselves properly and protect their stoma from water ingress, and when taking a bath, it is not possible to lie down and soak without stress, because protecting the tracheostomy tube from flooding very often causes anxiety and resulting limitations. The most rarely indicated results concerning the consequences of larynx removal concerned pushing. Only a few respondents noted that laryngectomy results in being unable to have a natural childbirth, lift weights, pass stool or urinate - all of which are also related to pushing.

Based on the statistical analyses carried out, it was established that there is no connection between gender, age, major and the number of smokers in the students' immediate circles and the knowledge of the consequences of laryngectomy. The correlation also applied to smokers.

The majority of smokers in the study group are students of education. One question that remains unanswered is whether the fact of their addiction to nicotine will play a role in prevention and health promotion activities during weekly class meetings.

The ranks of smokers also included students of speech therapy, vocal studies and medicine, namely those who should have high level of knowledge about the factors damaging the larynx and the consequences of smoking, which should convince them not to smoke. Among those students, the level of knowledge also turned out to be varied.

It cannot be overlooked that women dominated the group of smokers, which can be probably linked to the majors dominated by them. However, there is a marked increase in prevalence of nicotinism in women, and thus an increase in the incidence of laryngeal cancer. ${ }^{27}$

27 Z. Wronkowski, S. Brużewicz, Epidemiologia nowotworów złośliwych w Polsce i na świecie, [in:] Jeziorski A., Szawłowski A., Towpik E. (eds), Chirurgia onkologiczna, vol. 1, PZWL, Warsaw 2017. 
Reducing the number of people who smoke cigarettes is currently one of the most important objectives of health policies in countries around the world. ${ }^{28}$ National social programmes and the attempts to implement systemic solutions (National Health Programme 2005-2015, as well as social campaigns Rzuć palenie razem z nami and Palenie jest stabe by MANKO Association, co-financed by the Ministry of Health. ${ }^{29}$ Also worthy of note is the Anti-Tobacco Health Education Programme by Burgiel-Matusiewicz and Dziurla, ${ }^{30}$ addressed to children aged 9-10. The authors assumed primary school lays down the foundation for further education, introduces students to the world of knowledge, while taking care of their harmonious intellectual, ethical, emotional, physical and health development. The programme is a source of reliable knowledge about smoking, demonstrating the benefits of avoiding nicotine and tobacco.

Giving up smoking becomes an increasingly popular phenomenon; however, all kinds of preventive measures should be directed at reducing the number of people deciding to pick up smoking in the first place. In the opinion of students, knowledge about the harmful effects of smoking should be disseminated primarily in schools. ${ }^{31}$ Smoking among students of medical universities is a somewhat worrying issue. This state of affairs shows that having knowledge of consequences is hardly enough as a sufficient deterrent to smoking. 32 Perhaps more emphasis should be put to the way

${ }^{28}$ M. Szpringer, A. Makowska, M. Olędzka, Uzależnienie od nikotyny i ocena skuteczności rzucania palenia u dorostych. Medycyna Środowiskowa - Enviromental Medicine, 2016, 19(1), pp. 43-50.

${ }^{29}$ Ł. Bojkowski, E. Mojs, Palenie tytoniu i konsekwencje tego nałogu dla zdrowia osób w podeszłym wieku, Polski Przegląd Nauk o Zdrowiu, 2017, 2(51), pp. 220-224.

${ }^{30}$ K. Burgiel-Matusiewicz, R. Dziurla (2010). Program antytytoniowej edukacji zdrowotnej. Chief Sanitary Inspectorate, Warsaw.

31 J. Książek, J. Korczyńska, S. Terech, Problem nikotynizmu w aspekcie profilaktyki raka płuca wśród studentów gdańskich uczelni, Medycyna Rodzinna, 2013, 4, pp. 137-142.

32 A. Kułak, A. Shpakow, P. Kułak, Wstępna analiza problemu nikotynizmu, alkoholizmu $i$ narkomanii w populacji studentów. Problemy Higieny i Epidemiologii, 2011, 92(1), pp. 137-145. 
this knowledge is disseminated and communicated, which is shown by the study conducted by Kruk, Hubert-Lutecka, Zając and Cichocka. ${ }^{33}$ Researchers showed that knowledge of the health effects of smoking was the biggest motivation for public health students to quit smoking.

The enormous progress of medicine, earlier diagnostics and better treatment result in higher chances of recovery, despite coming down with a fatal disease in life. However, the treatment often results in irreversible changes in the form of losing access to selected activities or needing to change the way they are carried out. As Stokłosa, Skoczylas, Rudnicka, Bednarek, Krzyżanowski and Górecka note ${ }^{34}$ :

"this shows a strong need to educate the public on health knowledge the health-related motivations are usually the key to making binding decisions on quitting smoking".

As Bielska et al. point out, the topics related to nicotinism are not prevalent enough in the medical studies curriculum. ${ }^{35}$ The authors propose that family medicine subject should concern practical interventions and nicotine dependence prevention.

It would be worthwhile to include information on the consequences of treatment of selected diseases in the campaigns. Health education is an important element of the overall educational impact, and it is advisable that smoking prevention is one of the important educational tasks, even among the youngest students.

${ }^{33}$ W. Kruk, A. Hubert-Lutecka, K. Zając, I. Cichocka, Palenie tytoniu przez studentów - skala problemu, Medycyna Ogólna i Nauki o Zdrowiu, 2004, 20(4), pp. 433-438.

34 A. Stokłosa, A. Skoczylas, A. Rudnicka, M. Bednarek, K. Krzyżanowski, D. Górecka, Ocena motywacji do rzucenia palenia u pacjentów poradni antynikotynowej, Pneumonolgia i Alergologia Polska, 2010, 3, pp. 211-215

${ }^{3}$ D. Bielska, E. Trofimiuk, D. Kurpas, Program nikotynizmu w świetle edukacji na Wydziale Lekarskim i Wydziale Pielegniarstwa Uniwersytetu Medycznego w Białymstoku, Przegląd Lekarski, 2008, 65, 10, pp. 568-571. 


\section{References}

Bielska D., Trofimiuk E., Kurpas D., “Program nikotynizmu w świetle edukacji na Wydziale Lekarskim i Wydziale Pielęgniarstwa Uniwersytetu Medycznego w Białymstoku", Przegląd Lekarski, 2008, 65, 10, pp. 568-571.

Bojkowski Ł., Mojs E., "Palenie tytoniu i konsekwencje tego nałogu dla zdrowia osób w podeszłym wieku", Polski Przegląd Nauk o Zdrowiu, 2017, 2(51), pp. 220-224.

Brzezińska I., Trzeciak-Bilska K., “Wybrane aspekty polskiego prawa antytytoniowego jako narzędzia ograniczającego epidemię palenia tytoniu", Annales Academiae Medicae Gedanensis, 2012. 42, pp. 81-94.

Bruzgielewicz A., "Leczenie chirurgiczne”, [in:] Janczewski G., Osuch-Wójcikiewicz E. Rak krtani i gardła dolnego, Bielsko-Biała 2002, pp. 143-175.

Burgiel-Matusiewicz K., Dziurla R. (2010). Program antytytoniowej edukacji zdrowotnej. Chief Sanitary Inspectorate, Warsaw.

Doll R., Peto R., Boreham J., Sutherland I., "Mortality in relation to smoking: 50 years' observations on male British doctors", BMJ, 2004 26, 328(7455), 1519, https://www.bmj.com/content/bmj/328/7455/1519.full.pdf

Galbe, José Traver, P. Navarra, B. Martínez, A. Galve, Z. Aliaga, Y. Duplá, M. Jimenez, V. Torres, S. Cazorla, Ibarrondo, I. Magallón-Botaya, R. OlivánBlázquez, B. Alastuey, M. Escosa, L. Planas, E., “Brief advice for the prevention of the nicotinism in students of $2^{\circ}$ to $4^{\circ}$ of Secondary Obligatory Education of Saragossa", Pediatria de Atencion Primaria, 2009, 11, pp. 49-63.

Hamerlińska-Latecka A., "Metodyka logopedyczna w przypadku osób po laryngektomii całkowitej", Studia Logopaedica, 2017, VI, pp. 89-100.

Kamuda-Lewtak J., “Typologia zaburzeń mowy w chorobach nowotworowych krtani", [in:] Grabias S., Kurkowski M. (eds.), Logopedia - Teoria zaburzeń mowy, Podręcznik akademicki, Lublin, 2015, pp. 515-527.

Kanicka M., Krupicka A., Krysińska M., Lewkowicz M., Mania S., Kowalska A., Szpak A., "Wiedza i postawy studentów kierunku Zdrowie Publiczne Uniwersytetu Medycznego w Białymstoku dotycząca nikotynizmu", Problemy Higieny i Epidemiologii, 2010, 90(3), pp. 415-423.

Kruk W., Hubert-Lutecka A., Zając K., Cichocka I., "Palenie tytoniu przez studentów - skala problemu", Medycyna Ogólna i Nauki o Zdrowiu, 2004, 20 (4), pp. 433-438.

Książek J., Korczyńska J., Terech S., “Problem nikotynizmu w aspekcie profilaktyki raka płuca wśród studentów gdańskich uczelni", Medycyna Rodzinna, 2013, 4, pp. 137-142.

Kułak A., Shpakow A., Kułak P., “Wstępna analiza problemu nikotynizmu, alkoholizmu i narkomanii w populacji studentów". Problemy Higieny $i$ Epidemiologii, 2011, 92(1), pp. 137-145. 
Launer L.J., Andersen K., Dewey M.E., Letenneur L., Ott A., Amaducci L.A., Brayne C., Copeland J.R., Dartigues J.F., Kragh-Sorensen P., Lobo A., Martinez-Lage J.M., Stijnen T., Hofman A., "Rates and risk factors for dementia and Alzheimer's disease: results from EURODEM pooled analyses. EURODEM Incidence Research Group and Work Groups", European Studies of Dementia. Neurology 1999, 1, 52(1), pp. 78-84.

Łukasik M., Kozubski W., “Zespół metaboliczny jako czynnik ryzyka niedokrwiennego udaru mózgu", Neurologia i Neurochirurgia Polska, 2012, 46, pp. 271-278.

Stokłosa A., Skoczylas A., Rudnicka A., Bednarek M., Krzyżanowski K., Górecka D., "Ocena motywacji do rzucenia palenia u pacjentów poradni antynikotynowej", Pneumonolgia i Alergologia Polska, 2010, 3, pp. 211-215.

Szczygieł Ł., “Uzależnienie od tytoniu”. Gazeta Farmaceutyczna, 2008, 4, pp. 42-45.

Szpringer M., Makowska A., Olędzka M., “Uzależnienie od nikotyny i ocena skuteczności rzucania palenia u dorosłych". Medycyna Środowiskowa - Enviromental Medicine, 2016, 19(1), pp. 43-50.

Wengler L., Popowski P., Adamska-Pietrzak E., Balwicka-Szczyrba M., Balwicki Ł., Adrych-Brzezińska I., Trzeciak-Bilska K., “Wybrane aspekty polskiego prawa antytytoniowego jako narzędzia ograniczającego epidemię palenia tytoniu", Annales Academiae Medicae Gedanensis. 2012, 42, pp. 81-94.

Wronkowski Z., Brużewicz S., “Epidemiologia nowotworów złośliwych w Polsce i na świecie”, [in:] Jeziorski A., Szawłowski A., Towpik E. (eds), Chirurgia onkologiczna, vol. 1, PZWL, Warsaw, 2017. 